University of Nebraska - Lincoln

DigitalCommons@University of Nebraska - Lincoln

Agronomy \& Horticulture -- Faculty Publications

Agronomy and Horticulture Department

2009

\title{
Limits to maize productivity in the Western Corn-Belt: A simulation analysis for fully irrigated and rainfed conditions
}

\author{
Patricio Grassini \\ University of Nebraska-Lincoln, pgrassini2@unl.edu \\ Haishun Yang \\ University of Nebraska-Lincoln, hyang2@unl.edu \\ Kenneth G. Cassman \\ University of Nebraska-Lincoln, kcassman1@unl.edu
}

Follow this and additional works at: https://digitalcommons.unl.edu/agronomyfacpub

Part of the Agronomy and Crop Sciences Commons, and the Terrestrial and Aquatic Ecology

Commons

Grassini, Patricio; Yang, Haishun; and Cassman, Kenneth G., "Limits to maize productivity in the Western Corn-Belt: A simulation analysis for fully irrigated and rainfed conditions" (2009). Agronomy \& Horticulture -- Faculty Publications. 312.

https://digitalcommons.unl.edu/agronomyfacpub/312

This Article is brought to you for free and open access by the Agronomy and Horticulture Department at DigitalCommons@University of Nebraska - Lincoln. It has been accepted for inclusion in Agronomy \& Horticulture -Faculty Publications by an authorized administrator of DigitalCommons@University of Nebraska - Lincoln. 


\title{
Limits to maize productivity in the Western Corn-Belt: A simulation analysis for fully irrigated and rainfed conditions
}

\author{
Patricio Grassini, Haishun Yang, and Kenneth G. Cassman \\ Department of Agronomy and Horticulture, University of Nebraska-Lincoln, P.O. Box 830915, Lincoln, NE 68583-0915, USA \\ Corresponding author - K. G. Cassman, email kcassman1@unl.edu
}

\begin{abstract}
Unlike the Central and Eastern U.S. Corn-Belt where maize is grown almost entirely under rainfed conditions, maize in the Western Corn-Belt is produced under both irrigated (3.2 million ha) and rainfed (4.1 million ha) conditions. Simulation modeling, regression, and boundary-function analysis were used to assess constraints to maize productivity in the Western CornBelt. Aboveground biomass, grain yield, and water balance were simulated for fully irrigated and rainfed crops, using 20year weather records from 18 locations in combination with actual soil, planting date, plant population, and hybrid-maturity data. Mean values of meteorological variables were estimated for three growth periods (pre- and post-silking, and the entire growing season) and used to identify major geospatial gradients. Linear and stepwise multiple regressions were performed to evaluate variation of potential productivity in relation to meteorological factors. Boundary functions for water productivity and water-use efficiency were derived and compared against observed data reported in the literature. Geospatial gradients of seasonal radiation, temperature, rainfall, and evaporative demand along the Western Corn-Belt were identified. Yield potential with irrigation did not exhibit any geospatial pattern, depending instead on the specific radiation/temperature regime at each location and its interaction with crop phenology. A linear and parabolic response to post-silking cumulative solar radiation and mean temperature, respectively, explained variations on yield potential. Water-limited productivity followed the longitudinal gradient in seasonal rainfall and evaporative demand. Rainfed crops grown in the Western Corn-Belt are frequently subjected to episodes of transient and unavoidable water stress, especially around and after silking. Soil water at sowing ameliorates, but does not eliminate water stress episodes. Boundary functions for water productivity had slopes of 46 and $28 \mathrm{~kg} \mathrm{ha}^{-1} \mathrm{~mm}^{-1}$, for aboveground biomass and grain yield, respectively. At high seasonal water supply, productivity was weakly correlated with water supply because many crops did not fully utilize seasonally available water due to percolation below the root zone or water left in the ground at physiological maturity. Fitted boundary functions for wateruse efficiency had slopes ( $\approx$ seasonal transpiration-efficiency) of 54 and $37 \mathrm{~kg} \mathrm{ha}^{-1} \mathrm{~mm}^{-1}$ for aboveground biomass and grain yield, respectively, and an $x$-intercept around 25-75 $\mathrm{mm}$ ( $\approx$ seasonal soil evaporation). Data collected from experiments conducted in low-rainfall environments indicated that the boundary functions for water-use efficiency, derived from this study, are broadly applicable.
\end{abstract}

Keywords: corn, maize, Zea mays L., yield potential, water-limited yield, simulation model, rainfall shortage, water productivity, water-use efficiency

\section{Introduction}

Yield potential is defined as the yield of a crop cultivar when grown in an environment to which it is adapted, with nutrient and water non-limiting and pests and diseases effectively controlled (Evans, 1993). Hence, yield potential for a given genotype is determined by the particular combination of solar radiation, temperature and plant population at a specific location (van Ittersum and Rabbinge, 1997). Yield potential can be diminished as a consequence of insufficient water supply to meet crop water demand. Thus, water-limited yield is determined by the genotype, solar radiation, temperature, plant population and the degree of water limitation (Loomis and Connor, 1992). Insufficient water supply can result from sub-optimal seasonal water supply (stored soil water plus growing-season rainfall) in rainfed systems or suboptimal irrigation in irrigated systems. Accurate quantification of yield potential and water-limited limited yield is essential to estimate the magnitude of the exploitable gap between actual (i.e., those achieved by farmers) and attainable yields, to predict global change scenarios, and to help formulate policies to ensure local and global food security (Cassman et al., 2003). The lack of data from experiments in which yield-limiting factors have been ef- 
fectively controlled makes it difficult to obtain reliable quantifications of yield-potential and water-limited yield based on actual measurements (Duvick and Cassman, 1999). When such data are lacking, simulation models can provide reasonable estimates of yield potential and water-limited yields when soil and historical daily weather data are available, including solar radiation, daily temperature, and rainfall (e.g., Amir and Sinclair, 1991a; Amir and Sinclair, 1991b; Yang et al., 2004).

Although maize production is expected to increase substantially to meet the rapidly increasing demand for food, livestock feed, and biofuel at a global scale (Cassman et al., 2003; Cassman and Liska, 2007), there has been little increase in maize yield potential in the last 30 years (Duvick and Cassman, 1999; Tollenaar and Lee, 2002). Studies attempting to understand maize yield potential and its variation in relation to environmental factors have highlighted the crucial role of solar radiation and temperature (Muchow, 1989; Cirilo and Andrade, 1994; Otegui et al., 1995; Otegui et al., 1996). A few studies have attempted to quantify yield potential and its variation at a regional scale using observed data (Duncan et al., 1973; Andrade et al., 1996) and simulation modeling (Hodges et al., 1987; Muchow et al., 1990; Wilson et al., 1995; Löffler et al., 2005). In all of these studies, maize yields were evaluated against mean meteorological variables for the entire growing season rather than specific growth phases that are most sensitive to environmental limitations (Otegui and Bonhomme, 1998). Likewise, it was not clear if the practices used at all locations were optimal for maximum attainable yield. As a result, measured or simulated yields appear to be well below maize yield potential. Finally, simulation models such as CERES-Maize (Jones and Kiniry, 1986) and the Muchow-Sinclair-Bennett model (Muchow et al., 1990) do not account explicitly for direct effects of temperature on gross carbon assimilation and respiration, which may have a significant impact on yield estimates in cool or warm environments (e.g., Edmeades and Bolaños, 2001).

Water resources for agriculture are heavily exploited and there is increasing competition for limited water supplies in most countries with extensive irrigated agriculture (Rosegrant et al., 2002). Therefore, quantifying the maximum yield per unit of available water supply, hereafter called the water-limited yield, is essential for identifying water management practices and policies to optimize water-use efficiency (Wallace, 2000). Boundary functions provide a robust framework to analyze water-limited productivity (e.g., French and Schultz, 1984; Passioura, 2006; Sadras and Angus, 2006). Yield is plotted against either: (i) water supply (stored soil water at sowing plus rainfall), or (ii) crop evapotranspiration $\left(\mathrm{ET}_{\mathrm{C}}\right)$, on a seasonal basis, and a linear function is fitted to those data that delimit the upper frontier for yield. The first approach, namely water productivity (WP), provides a benchmark to help farmers set target yields and identify other yield reducing-factors, such as nutrients, pests, and diseases (Passioura, 2006). The second approach based on $\mathrm{ET}_{\mathrm{C}^{\prime}}$ namely water-use efficiency (WUE), provides a physiological frontier for water-limited productivity in which the slope represents the seasonal transpiration-efficiency $\left(\mathrm{TE}_{\mathrm{S}}\right)$ and the $x$-intercept gives a rough estimate of seasonal soil evaporation (Sinclair et al., 1984). Despite the large number of reported yield/water supply relationships reported for maize, we were not able to find any explicit attempt to define maximum boundary functions for water productivity or water-use efficiency.

To fill this knowledge gap about maize productivity and its variability, we used a crop simulation model (Yang et al., 2004), regression and boundary function analysis to assess limits to maize aboveground biomass and grain yield in the Western Corn-Belt. The primary objectives of this work were to: (i) identify geospatial patterns of radiation, temperature, rainfall, reference evapotranspiration, and water-stress; (ii) explain geospatial variations in potential and water-limited productivity in relation to these climate variables; and (iii) determine boundary functions for water productivity and water-use efficiency.

\section{Materials and methods}

\subsection{The Western Corn-Belt}

The Western U.S. Corn-Belt $\left(37-45^{\circ} \mathrm{N} ; 92-105^{\circ} \mathrm{W}\right)$ includes about 7.3 million ha cultivated with maize, mostly located in Kansas, Nebraska, and South Dakota states (Figure 1) (USDA-NASS, 2003-2007). Irrigated maize represents $43 \%$ of the total maize area (70\% of the total irrigated cropland in the region) and accounts for $58 \%$ of the total annual maize production of 60 million $\mathrm{Mg}$ in the Western Corn-Belt. Average county-level yields range from 2.4 to $8.1 \mathrm{Mg} \mathrm{ha}^{-1}$ under rainfed conditions, and from 8 to $11.2 \mathrm{Mg} \mathrm{ha}^{-1}$ with irrigation. These values are well below the highest reported yields for rainfed (9-16 $\left.\mathrm{Mg} \mathrm{ha}^{-1}\right)$ and irrigated maize (15$21 \mathrm{Mg} \mathrm{ha}^{-1}$ ) in the region (Duvick and Cassman, 1999).

Soil and climate in the region are described by Smika (1992). The landscape is undulate. Predominant agricultural soils are Haplustolls and Argiustolls with medium-to-high water holding capacity. Elevation increases by $118 \mathrm{~m}$ per longitude degree, from east to west (range: $309 \mathrm{~m}$ in Ames, IA to $1384 \mathrm{~m}$ in Akron, $\mathrm{CO})$. The climate is continental and temperate, and the frost-free period decreases from the southeast to the northwest along the altitudinal gradient. Annual rainfall decreases from east to west, and its distribution follows a monsoonal pattern: $70-80 \%$ of the precipitation is concentrated in the spring and summer seasons. Evaporative demand exceeds rainfall during the summer growing-season such that most rainfed crops depend on stored soil moisture that accumulates from snow melt and spring rains (Loomis and Connor, 1992).

\subsection{Model evaluation}

Hybrid-Maize (Yang et al., 2004, 2006) is a process-oriented model that simulates maize development and growth on a daily time step under growth conditions without limitations from nutrient deficiencies or toxicities, or from insect pests, diseases, or weeds. It features temperature-driven maize development, vertical canopy integration of photosynthesis, organ-specific growth respiration, and temperature-sensitive maintenance respiration.

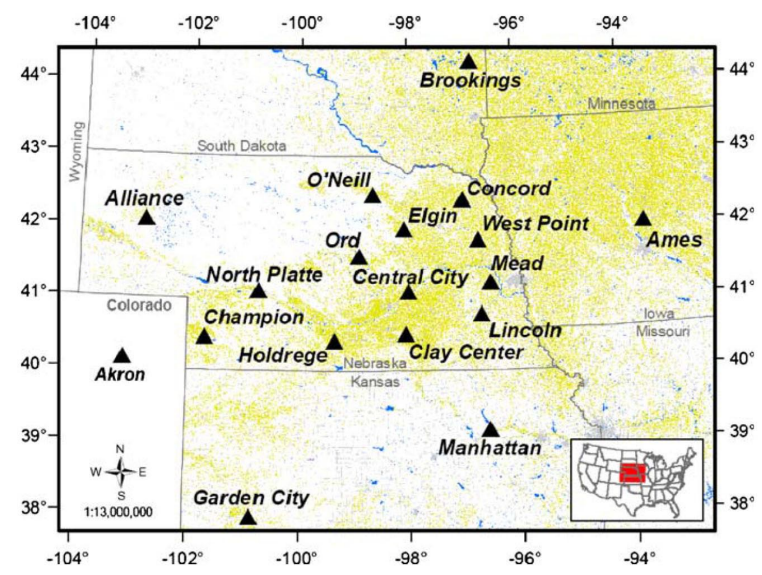

Figure 1. Map of the Western U.S. Corn-Belt. States are named and their boundaries shown. Triangles indicate sites of meteorological stations used in this study. Inset shows location of area within the United States. Maize (yellow), water (blue), and urban (grey) areas are shown, except for Wyoming and Colorado (data not available). 
Table 1. Dataset for Hybrid-Maize validation for rainfed and fully irrigated crops.

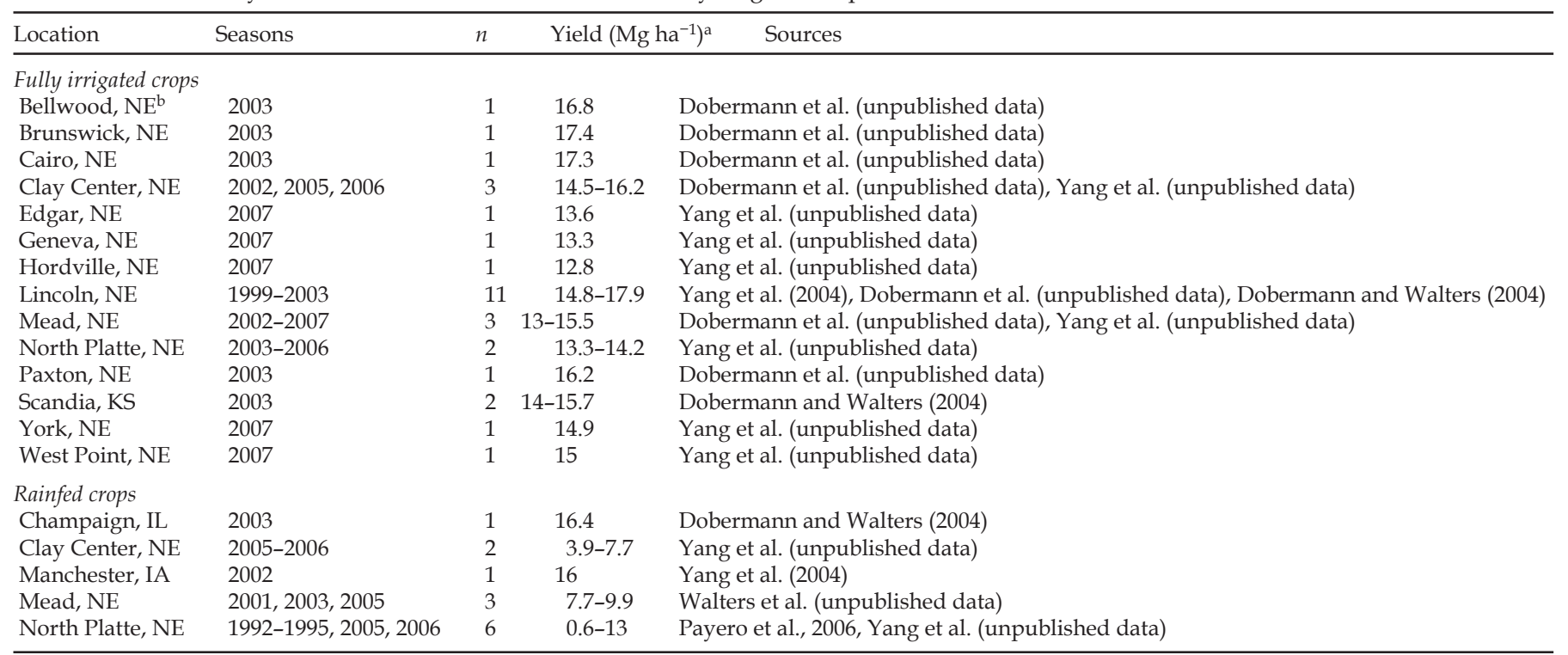

${ }^{a}$ Measured yields at standard moisture, $0.155 \mathrm{~kg} \mathrm{H}_{2} \mathrm{O} \mathrm{kg}{ }^{-1}$ grain.

${ }^{\mathrm{b}}$ Locations and corresponding USA state (IL: Illinois; IA: Iowa; KS: Kansas; NE: Nebraska).

Simulation of photosynthesis, growth respiration and maintenance respiration may make the Hybrid-Maize model more responsive to changes in environmental conditions than models such as CERES-Maize or the Muchow-Sinclair-Bennett model, which utilize radiation-use efficiency (RUE) to integrate the processes of assimilation and respiration. The results presented here extend the original model validation reported by Yang et al. (2004).

Maize yields were obtained from field studies conducted over 43 site-years that including rainfed $(n=13)$ and fully irrigated $(n=30)$ field studies (Table 1$)$. The database did not include fields with obvious limitations due to nutrient deficiencies, diseases, insects, weeds, hail or waterlogging. Simulated grain yields were compared against observed values and root mean square error (RMSE) was calculated. For rainfed crops, available soil water at sowing $\left(\mathrm{ASW}_{\mathrm{S}}\right)$ was estimated based on rainfall during the period from October to the planting date at each site, soil water holding capacity, and simulated ASW left in the ground by the previous maize crop (data not shown). Temperature and radiation data were obtained from the nearest meteorological station, which, on average, was located $\approx 14 \mathrm{~km}$ away from each field (range: 0-40 km). Rainfall was recorded at the field study site in $75 \%$ of the site-years or at the nearest meteorological station. Simulations were based on the actual soil texture, planting date, plant population, and hybrid used at each site. Grain yields for this model evaluation, and for all other simulations in this paper, are reported at a standard moisture content of $0.155 \mathrm{~kg} \mathrm{H}_{2} \mathrm{O} \mathrm{kg}{ }^{-1}$ grain.

\subsection{Simulated yield and water balance}

Rainfed and irrigated yield were simulated at 18 sites across the Western Corn-Belt (Figure 1). Grain yield, aboveground biomass on an oven-dry basis, and water balance components [soil evaporation, crop evapotranspiration $\left(\mathrm{ET}_{\mathrm{C}}\right)$, percolation below root zone, and residual ASW at maturity] were simulated using long-term (20-year) weather records. Simulations utilized the actual soil type, average sowing date, and the recommended hybrid-maturity for each site (Table 2). Average sowing date was the date when $50 \%$ of the total maize area was planted according to 2004-2006 county-level report on planting progression obtained from the Risk Management Agency-USDA (Rebecca Davis, personal communication). The predominant soil series suitable for maize production was identified in an area of $710 \mathrm{~km}^{2}$ around each meteorological station using STATSGO (USDA, 1994) and SSURGO (USDA, 1995) databases, and the soil texture of that soil series, derived from the official soil series descriptions (USDA-NRCS), was specified in the rainfed simulations because soil water retention and release characteristics are based on soil texture in Hybrid-Maize. None of these soils have physical impediments to root growth and so root depth was set at $1.5 \mathrm{~m}$, based on soil water extraction patterns reported by Payero et al. (2006).

The recommended plant population and hybrid-maturity for each location were provided by agronomists from a major seed company. A fixed plant population $\left(80,000\right.$ plants $\left.\mathrm{ha}^{-1}\right)$ was set for irrigated crops because recommended population did not vary across locations with irrigation. In contrast, recommended plant populations varied from 32,000 to 78,000 plants ha ${ }^{-1}$ along the west-east gradient of increasing rainfall (Table 2; Appendix A, Figure A1). Site-years in which minimum temperature fell below freezing during grain-filling were not allowed to exceed $25 \%$ of the 20 -year simulation period (Table 2). Simulations ended at physiological maturity for the recommended hybrid at each site. Two $\mathrm{ASW}_{\mathrm{S}}$ scenarios were simulated for rainfed crops: fully recharged profile (FRP, whole profile at 100\% ASW) and partially recharged profile (PRP; upper $0.3 \mathrm{~m}$ at $100 \%$ ASW, rest of the profile at $25 \%$ ASW). The scenarios are representative of the expected range in $\mathrm{ASW}_{\mathrm{S}^{\prime}}$ based on: (i) 3-year ASW data at eight locations between 97 and $104^{\circ} \mathrm{W}$ along the east-west rainfall gradient (data provided by the High-Plains Regional Climate Center), (ii) 20-year water balance computations during the fallow's period, and (iii) our expert opinion.

\subsection{Geospatial patterns of meteorological variables and productivity}

For each site-year simulation, mean values for the following meteorological variables were estimated: daily and cumulative incident solar radiation, daily maximum $\left(T_{\text {max }}\right)$, mean $\left(T_{\text {mean }}\right)$ and minimum temperature $\left(T_{\min }\right)$, daily relative humidity, cumulative rainfall, and cumulative $\mathrm{ET}_{\mathrm{O}}$ (estimated using Penman's equation). Means were calculated for the entire crop cycle 
Table 2. Dataset for modeling analysis of fully irrigated and rainfed maize yield at different locations in Western U.S. Corn-Belt using historical climate data (1986-2005).

\begin{tabular}{|c|c|c|c|c|c|c|}
\hline Location & $\begin{array}{l}\text { Dominant soil } \\
\text { series }\end{array}$ & $\begin{array}{l}\% \text { of total } \\
\text { agricultural land }\end{array}$ & Planting date ${ }^{b}$ & Hybrid-maturity $^{c}$ & $\begin{array}{c}\text { Plant } \\
\text { population }^{\mathrm{d}}\end{array}$ & $\begin{array}{c}\text { Frost } \\
\text { incidence }\end{array}$ \\
\hline Akron, $\mathrm{CO}^{\mathrm{f}}$ & Platner & 35 & 130 & 1400 & 32,000 & 15 \\
\hline Alliance, NE & Creighton & 57 & 128 & 1220 & $\mathrm{~g}$ & 20 \\
\hline Ames, IA & Clarion & 30 & 115 & 1472 & 78,000 & 10 \\
\hline Brooking, SD & Kranzburg-Brookings & 15 & 124 & 1172 & 74,000 & 20 \\
\hline Central City, NE & Holder & 20 & 119 & 1524 & 63,000 & 25 \\
\hline Champion, NE & Goshen & 10 & 125 & 1417 & 35,000 & 25 \\
\hline Clay Center, NE & Hastings & 43 & 113 & 1510 & 54,000 & 20 \\
\hline Concord, NE & Moody & 33 & 123 & 1382 & 67,000 & 20 \\
\hline Elgin, NE & Moody & 22 & 121 & 1438 & 54,000 & 15 \\
\hline Garden City, KS & Richfield & 40 & 121 & 1524 & 44,000 & 0 \\
\hline Holdrege, NE & Holdrege & 91 & 117 & 1510 & 49,000 & 10 \\
\hline Lincoln, NE & Aksarben & 37 & 113 & 1524 & 69,000 & 10 \\
\hline Manhattan, KS & Reading & 12 & 106 & 1510 & 59,000 & 0 \\
\hline Mead, NE & Yutan & 22 & 120 & 1524 & 64,000 & 5 \\
\hline North Platte, NE & Holdrege & 18 & 124 & 1405 & 44,000 & 20 \\
\hline $\mathrm{O}^{\prime}$ Neill, NE & Jansen & 53 & 123 & 1340 & 54,000 & 25 \\
\hline Ord, NE & Holdrege & 20 & 125 & 1450 & 58,000 & 20 \\
\hline West Point, NE & Moody & 40 & 120 & 1510 & 64,000 & 25 \\
\hline
\end{tabular}

a Percentage of the dominant soil series land suitable for maize production with respect to the total agricultural land in the area $\left(710 \mathrm{~km}{ }^{2}\right)$ surrounding each location. Data derived from STATSGO (USDA, 1994) and SSURGO (USDA, 1995) databases.

b Day of year.

c Sowing-to-physiological maturity growing degree days $\left(T_{\mathrm{b}}=10^{\circ} \mathrm{C}\right)$.

d Plant population for rainfed crops (plants ha ${ }^{-1}$ ). Plant population for fully irrigated crops was set at 80,000 plants ha ${ }^{-1}$ at all locations.

e Percentage of years with early frost during grain-filling.

${ }^{\mathrm{f}}$ Location and corresponding USA state (CO: Colorado; IL: Illinois; IA: Iowa; KS: Kansas; NE: Nebraska; SD: South Dakota).

$\mathrm{g}$ No significant rainfed maize production at this location.

(i.e., from sowing to physiological maturity), the pre-silking (i.e., from sowing to silking), and post-silking (i.e., from silking to physiological maturity) phases. 20-Year mean values at each location were then plotted against latitude and longitude to identify major geospatial gradients. Linear or second-order polynomial functions were fitted. A similar analysis was performed to identify geospatial patterns in potential and rainfed aboveground biomass and grain yield.

\subsection{Growing-season rainfall, evaporative demand, and water stress patterns}

Hybrid-Maize was used to evaluate seasonal rainfall, crop water use, and water stress patterns of rainfed maize over 20 years of weather data at Akron, $\mathrm{CO}$ and Mead, NE, which are representative of the longitudinal gradients of rainfall and $\mathrm{ET}_{\mathrm{O}}$ in the Western Corn-Belt (Figure 1). Model inputs for each site are shown in Table 2. The crop growth period, from sowing to physiological maturity, was divided into 20-day intervals. For each interval, mean and tercile values were calculated for $\mathrm{cu}^{-}$ mulative rainfall, cumulative maximum $\mathrm{ET}_{\mathrm{C}}$ (i.e., the $\mathrm{ET}_{\mathrm{C}}$ a crop would have when grown under non-water limiting conditions), and average water-stress index (WSI). Hybrid-Maize simulates maximum $\mathrm{ET}_{\mathrm{C}}$ as a function of the evaporative demand and leaf area. WSI is the ratio between actual transpiration and potential transpiration (range: 0 [no stress] to 1 [maximum stress]; see Yang et al., 2006). WSI patterns were simulated for the two $\mathrm{ASW}_{\mathrm{S}}$ scenarios (FRP and PRP initial soil water).

\subsection{Explanation of geospatial variation in aboveground biomass and grain yield}

Pearson's correlations between site-year means of meteorological variables (Section 2.4) and aboveground biomass or grain yield were evaluated for both fully irrigated and rainfed conditions for the entire growth cycle and the pre- and post-sillking phases. Stepwise multiple-regression analysis (Kleinbaum et al., 1998) was performed to explain the simulated variability in potential aboveground biomass and grain yield (dependent variables) on meteorological variables (independent variables). The objective was to determine whether using mean meteorological values for both the vegetative and reproductive phases as independent variables, instead of means for the entire crop growth cycle, can explain significantly more of the simulated variation in potential aboveground biomass and grain yield. Because there was a high degree of co-linearity between $T_{\text {mean }}$ and $T_{\text {max' }}$ and between $T_{\text {mean }}$ and $T_{\text {min }}$ (data not shown), stepwise regressions used either $T_{\text {mean }}$ or both $T_{\max }$ and $T_{\min }$. Cumulative solar radiation was chosen as an independent variable instead of daily radiation because: (i) the former integrates both daily radiation and differences in hybrid maturity among locations (Table 2), and (ii) daily radiation and $T_{\max }$ were highly correlated $(r \approx 0.7)$. Separate stepwise regression analyses $(p>0.05$ for variable rejection) were performed with different sets of independent variables for (i) the entire crop cycle and (ii) both pre- and post-silking phases. Additional quadratic terms for temperature were added into the model to account for curvilinear responses. The predictive value of each variable was quantified in terms of its relative contribution to the regression sum of squares (\%SSR), the latter computed as the difference between the total sum of squares and the residual sum of squares.

\subsection{Boundary-function analysis}

The quantile regression method of Cade and Noon (2003) was used to derive maximum boundary functions for the relationships between simulated aboveground biomass or grain yield and seasonal water supply $\left(\mathrm{ASW}_{\mathrm{S}}+\right.$ growing-season rainfall + irrigation) or $\mathrm{ET}_{\mathrm{C}}$. Fully irrigated $(n=295)$ and rainfed $(n=564)$ frost-free site-years were pooled across ASW $_{\mathrm{S}}$ scenarios. To derive the boundary function, seasonal water supply and $\mathrm{ET}_{C}$ values for the $200-800 \mathrm{~mm}$ and $200-600 \mathrm{~mm}$ intervals were split into 10 classes; these ranges represent the water supply and $\mathrm{ET}_{\mathrm{C}}$ levels in which grain yield is responsive to changes in water status. The 95th percentile of class biomass or yield was regressed against the water-availability or $\mathrm{ET}_{\mathrm{C}}$ mid-point of each class. Fitted functions represented the maximum boundary line for WP and WUE, respectively.

Boundary functions derived for WUE were compared against observed data for aboveground biomass $(n=263)$ or grain yield 
$(n=556)$ versus $\mathrm{ET}_{C^{\prime}}$ obtained from the literature for maize grown in low-rainfall environments (Appendix B). In these studies maize relied on stored ASW, seasonal rainfall, and in some cases, irrigation. Reported $\mathrm{ET}_{\mathrm{C}}$ was generally calculated as growing-season rainfall and irrigation plus the change in ASW of the root zone between sowing and harvest.

\section{Results}

\subsection{Model validation}

The Hybrid-Maize model simulated yields reasonably well in the Western Corn-Belt as 100\% and 70\% of predicted grain yield were within $\pm 15 \%$ of measured values for fully irrigated and rainfed crops, respectively, across a broad range of growth conditions and yield potential (Figure 2). Grain yield was overestimated at very low observed yields $\left(<2 \mathrm{Mg} \mathrm{ha}^{-1}\right)$ and for two cases in the moderate yield range between 6 and $9 \mathrm{Mg} \mathrm{ha}^{-1}$. Examination of climate data during the growing season for these four site-years identified severe water deficits during the 3 weeks immediately before and shortly after silking (data not shown). Although maize yields are highly sensitive to water deficits during the period immediately before and after silking through effects on pollination and kernel setting (Hall et al., 1982; Westgate and Boyer, 1986), Hybrid-Maize does not explicitly simulate the direct effects of water deficits on kernel number. It is therefore likely the discrepancies between observed and simulated values in these four siteyears were due to lack of adequate sensitivity in the Hybrid-Maize model to severe moisture deficits during the silking window.

\subsection{Geospatial gradients of climate and crop water demand}

Geospatial trends in meteorological variables differed for cumulative solar radiation and $T_{\text {mean }}$ depending on the crop growth time period and direction. For example, while $T_{\text {mean }}$ was relatively constant across the longitudinal gradient of the Western Corn-Belt, cumulative solar radiation increased from $2560 \mathrm{MJ} \mathrm{m}^{-2}$ in the east to $3203 \mathrm{MJ} \mathrm{m}^{-2}$ in the west, and this gradient was most pronounced in the pre-silking growth period (Figure 3(a)-(c)). In contrast, cumulative solar radiation was relatively constant across the latitudinal gradient while $T_{\text {mean }}$ for the entire growing season increased from $18.5^{\circ} \mathrm{C}$ in the north to $22.4^{\circ} \mathrm{C}$ in the south, and this increase was most pronounced in the post-silking phase (Figure 3(d)-(f)). $T_{\max }$ increased from north-south in both the pre- and post-silking phases $(p<0.0001$, $r^{2}=0.61$ and 0.76 , respectively), while no latitudinal variation in $T_{\min }$ was detected (data not shown). The length of the freefrost season also increased from north-south (data not shown). Although $T_{\text {mean }}$ was similar across longitude, the mean thermal amplitude (i.e., the difference between mean daily minimum and maximum temperature) increases dramatically in the eastwest direction $\left(p<0.0001, r^{2}=0.92\right)$.

Longitudinal gradients were found for seasonal rainfall and $\mathrm{ET}_{\mathrm{O}}$ (Figure 3(g)-(i)), whereas both variables were relatively constant across the north-south direction (data not shown). From east to west, rainfall decreases (range: $210-555 \mathrm{~mm}$ ) while $\mathrm{ET}_{\mathrm{O}}$ increases (range: $485-790 \mathrm{~mm}$ ). $\mathrm{ET}_{\mathrm{O}}$ gradient was related to the increase in solar radiation (Figure $3(\mathrm{a})$ ) and decrease in relative humidity $\left(p<0.0001, r^{2}=0.89\right)$ in the east-west direction. At all locations, the variability in rainfall during the entire growing season was much greater across years than $\mathrm{ET}_{\mathrm{O}}$ (coefficient of variation $[\mathrm{CV}]=0.40$ for rainfall versus 0.12 for $\mathrm{ET}_{\mathrm{O}}$ ), especially during the post-silking phase (Figure 3(g)-(i)). Trends in the recommended rainfed plant population closely follow the eastwest rainfall and $\mathrm{ET}_{\mathrm{O}}$ gradients, reflecting management adaptation to reduced water supply (Appendix A, Figure A1).

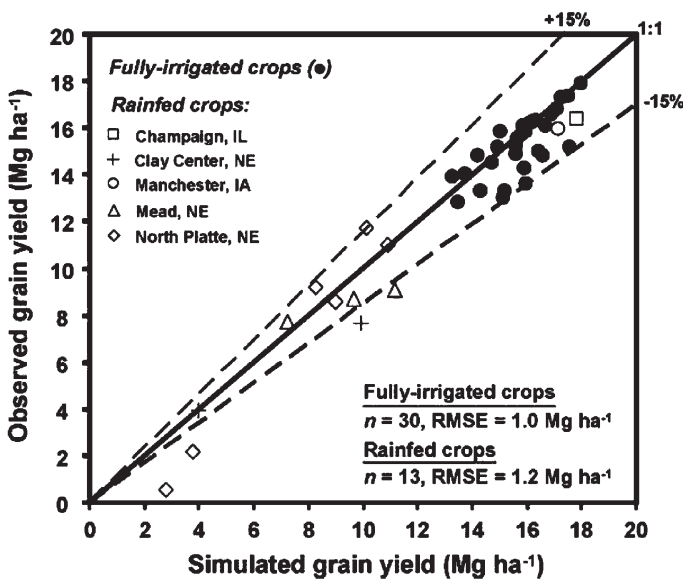

Figure 2. Observed vs. simulated yields for a test set of fully irrigated and rainfed maize crops grown in the U.S. Corn-Belt (see Table 1 for more details). Diagonal solid line: 1:1 ratio; dotted lines: $\pm 15 \%$ deviation from 1:1 line. Separate root mean square errors (RMSE) for fully irrigated and rainfed crops are shown.

\subsection{Seasonal patterns of rainfall, maximum $E T_{C}$ and water-stress index}

The mean and standard error (20-year) for rainfall during the entire growing-season were $286 \pm 33$ and $398 \pm 26 \mathrm{~mm}$ at Akron $\mathrm{CO}$ and Mead NE, respectively. At both locations, maximum $\mathrm{ET}_{\mathrm{C}}(820 \pm 13$ at Akron and $607 \pm 14 \mathrm{~mm}$ at Mead, respectively) exceeds growing-season rainfall by a large margin. While rainfall exceeds $\mathrm{ET}_{\mathrm{C}}$ in May, which is the first month after planting, it remains well below crop water demand throughout the remainder of the growing season, especially at Akron (Figure 4(a) and (b)), which represents the western edge of the longitudinal gradient in this study (Figure 1). Maximum crop water demand peaks in late June and early July, about 2 months after planting and remains relatively high throughout the remainder of the growing season (Figure 4(a) and (b)). Annual variation in rainfall was large at both locations for each 20-day period throughout the growing season $(\mathrm{CV}=0.85$ and 0.75 at Akron and Mead, respectively) compared to the much smaller annual variation in $\mathrm{ET}_{\mathrm{C}}(\mathrm{CV}=0.21$ and 0.25 , respectively). Simulated average WSI indicates that maize grown in the Western Corn-Belt will experience transient water stress events from pre-silking phase about 60 days after sowing until physiological maturity in most years with the magnitude and probability of water stress increasing as the season progresses (Figure 4(c) and (d)). Average stress severity was greater and more likely at Akron than in Mead, in agreement with the east-west gradient in rainfall and $\mathrm{ET}_{\mathrm{O}}$ (Figure $3(\mathrm{~g})-(\mathrm{i}))$. At both locations, greater stored soil moisture at sowing reduced the magnitude of water stress from pre-silking to maturity although the magnitude of reduction was relatively small (Figure 4(c) and (d)).

\subsection{Geospatial patterns in potential and water-limited yields}

Potential grain yield was not well correlated with longitudinal or latitudinal trends $(p>0.10)$, although highest yields were mostly achieved at intermediate latitudes $\left(40-42.5^{\circ} \mathrm{N}\right.$, data not shown). In contrast, there was a strong latitudinal gradient in potential aboveground biomass $(p<0.01, r=-0.81)$, mostly due to warmer daytime temperatures during the entire crop cycle. In rainfed crops, there was a sharp longitudinal gradient of aboveground biomass $(p<0.0005, r=0.76)$ and grain yield $(p<0.0001$, $r=0.81)$, associated with seasonal rainfall and $\mathrm{ET}_{\mathrm{O}}$ gradients (Figure 3(g)-(i), Table 3). Mean potential grain yield ranged from 

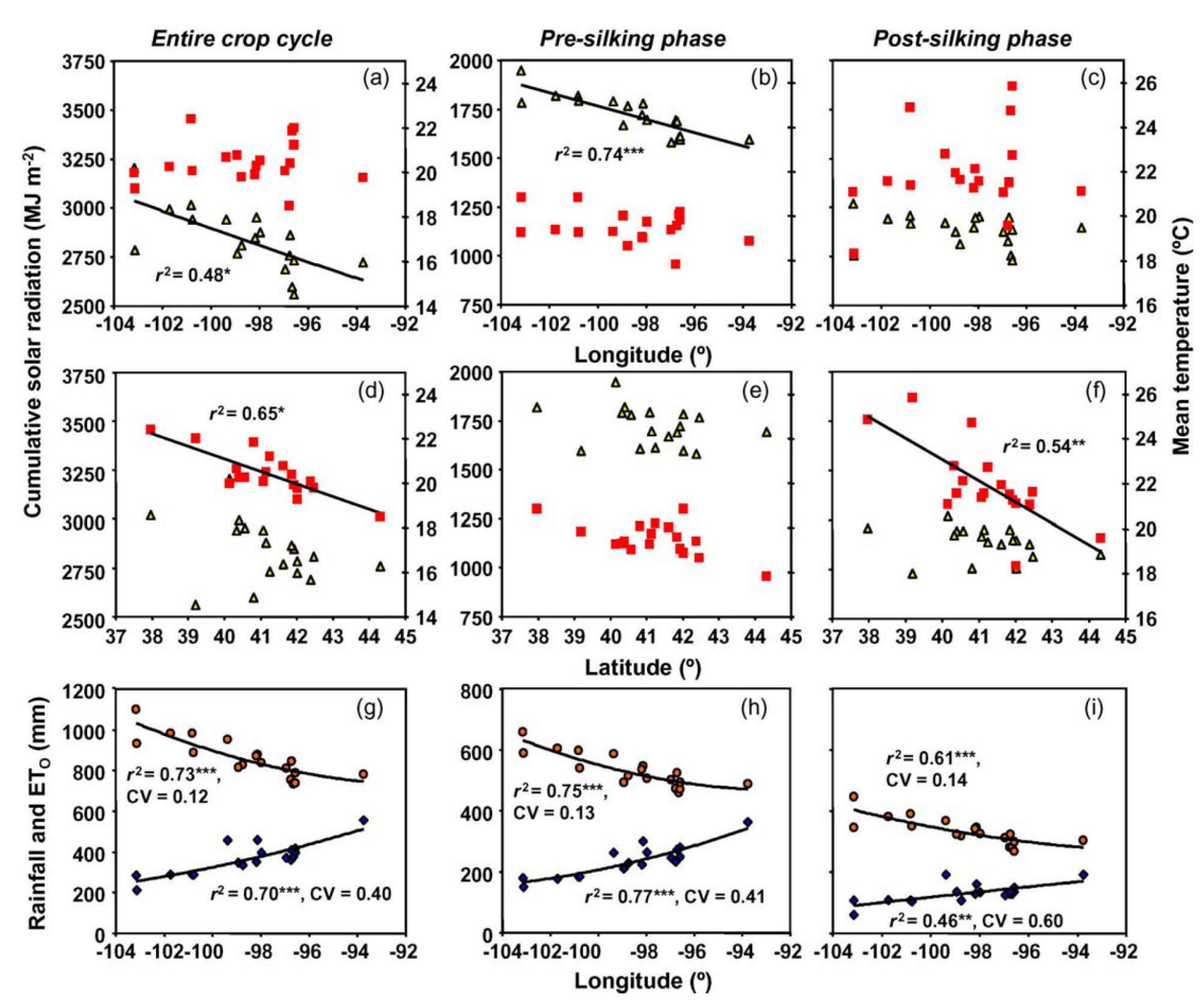

Figure 3. Longitudinal and latitudinal gradients of selected meteorological factors during the entire crop cycle (left panels), the pre-silking phase (central panels), and the post-silking phase (right panels). (a-f) Cumulative solar radiation (yellow triangles) and mean temperature (red squares); (g-i) cumulative rainfall (blue diamonds) and reference evapotranspiration (ET ${ }_{O^{\prime}}$ orange circles). No latitudinal gradients of cumulative rainfall and $\mathrm{ET}_{\mathrm{O}}$ were found, thus, these plots are not shown. Each point is the 20-year average for a given location. Crops affected by early frost were not accounted. SE ranges, across locations, between 34-82, 15-52, and 21-38 $\mathrm{MJ} \mathrm{m}^{-2}$ for cumulative solar radiation and between $0.2-0.3,0.2-0.4$, and $0.3-0.6^{\circ} \mathrm{C}$ for mean temperature, for the entire crop cycle, pre-, and post-silking phases, respectively. Average inter-annual coefficients of variation $(\mathrm{CV})$ for cumulative rainfall and $\mathrm{ET}_{\mathrm{O}}$ are shown. Asterisks indicate correlation at ${ }^{*} p<0.01,{ }^{* *} p<0.001$, and ${ }^{* * *} p<0.0001$.

11.4 to $16.1 \mathrm{Mg} \mathrm{ha}^{-1}$ across locations (mean: $14.4 \mathrm{Mg} \mathrm{ha}^{-1}$ ) with a relatively small degree of annual variation $(\mathrm{CV}=0.11)$. Maximum simulated grain yields $\left(\approx 17-20 \mathrm{Mg} \mathrm{ha}^{-1}\right)$ were similar to those reported by Duvick and Cassman (1999) for the same region. Rainfed yields were lower and considerably more variable:

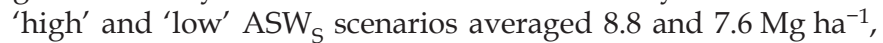
respectively (associated CVs $=0.27$ and 0.42 ). Mean potential aboveground biomass yield averaged $26.1 \mathrm{Mg} \mathrm{ha}^{-1}$ (range: $21.8-$ $30.5 \mathrm{Mg} \mathrm{ha}^{-1}, \mathrm{CV}=0.07$ ), while mean rainfed aboveground biomass yield was 16.9 and 15.5 for the 'high' and 'low' $\mathrm{ASW}_{\mathrm{S}}$ scenarios, respectively (associated CVs $=0.20$ and 0.27 ). For both irrigated and rainfed conditions, the CVs for total aboveground biomass yield were smaller than for grain yield, and this difference was greatest in rainfed situations.

Highest aboveground biomass yields were found at locations where the length of the growing season and the recommended hybrid maturity resulted in large cumulative solar radiation values (Table 3, Figure 5(a)), and where crops were subjected to warm temperatures during the vegetative phase (Table 3, Figure 5(b)). Potential grain yield was most closely associated with post-silking cumulative solar radiation (Table 3, Figure 5(c)). The significant parabolic relationship between simulated grain yield and post-silking $T_{\text {mean }}$ suggests that both high $\left(\approx>25^{\circ} \mathrm{C}\right)$ and low $\left(\approx<20^{\circ} \mathrm{C}\right)$ mean daily temperatures during grain filling reduce grain yield potential (Figure $5(\mathrm{~d})$ ). High post-silking $T_{\text {mean }}$ reduced grain-filling duration $\left(p<0.001, r^{2}=0.59\right)$ and also increased maintenance respiration as simulated by Hybrid-Maize (data not shown). On the other hand, low post-silking $T_{\text {mean }}$ re- duced both photosynthetic rates and kernel-growth rates (data not shown), and, in most cases, these effects were not offset by the increase in the grain-filling duration associated with low post-silking temperatures.

Stepwise regressions were performed separately for all siteyears $(n=351)$ and frost-free site-years $(n=295)$ to test for inconsistencies in the final regression model but the variables selected and their coefficients were of similar magnitude and sign (data not shown). Therefore, we used the frost-free regression. Stepwise multiple-regression that included meteorological means for both vegetative and reproductive growth phases explained $86 \%$ and $70 \%$ of the variation on simulated potential aboveground biomass and grain yield, respectively (data not shown). Pre- and post-silking cumulative solar radiation and pre-silking maximum daily temperature had the greatest influence on potential aboveground biomass (\%SSR $=35,30$, and $29 \%$, respectively; $p<0.0001)$. In contrast, potential grain yield was most closely related to post-silking cumulative radiation and mean daily temperature $(\%$ SSR $=89$ and $6 \%$, respectively; $p<0.001)$. The negative effects of high temperatures on potential grain yield during grain filling were reflected by a significant quadratic term for post-silking $T_{\text {mean }}(p<0.005)$. These results were consistent with the single-factor relationships quantified by Pearson's correlation (Table 3) and regression (Figure 5). Stepwise regressions using meteorological variable means for the entire growing season explained considerably less of the variation in simulated potential aboveground biomass and grain yield (adjusted $r^{2}=0.70$ and 0.48 , respectively). 


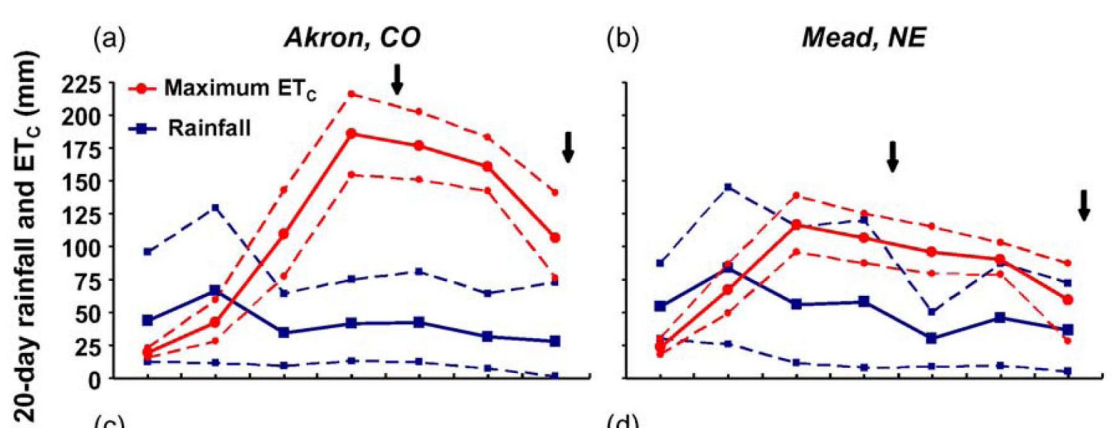

(c)

(d)

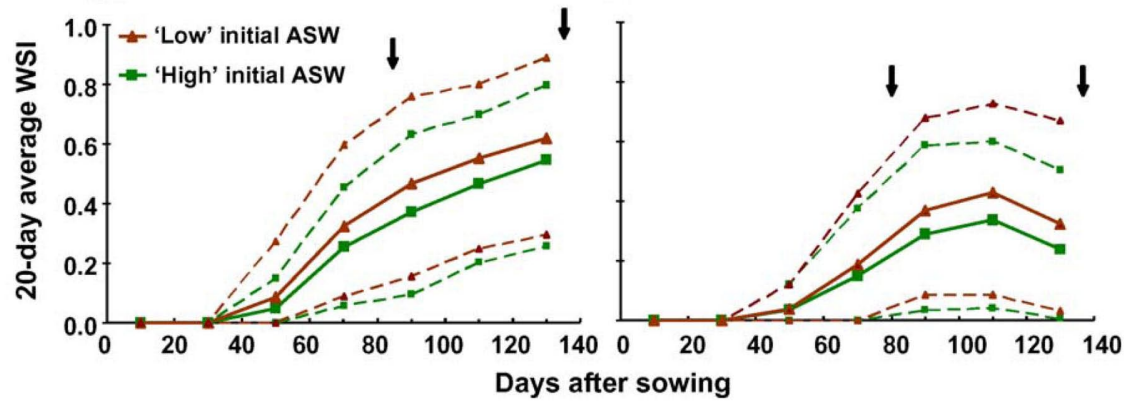

Figure 4. Patterns of long-term (a and b) 20-day cumulative rainfall and crop evapotranspiration, under non-limiting water supply (ET , $_{\text {, and }}(\mathrm{c}$ and d) 20-day average water-stress index (WSI) in simulated rainfed crops for two scenarios of available soil water (ASW) at sowing. Each point represents a 20-day interval. Solid thick lines: means; dashed thin lines: upper and lower terciles. Data come from selected stations in the area of interest, Akron, CO (right panels) and Mead, NE (left panels) (see Figure 1). Sowing dates were 10 May and 30 April at Akron and Mead, respectively. Vertical arrows indicate average simulated dates of silking and physiological maturity (left and right arrows, in each figure, respectively).

\subsection{Boundary functions for water productivity and water-use efficiency}

Rainfed maize yields were limited by the amount of water supply (Figure 6(a) and (b)). Fitted boundary functions for WP had slopes of $46.0 \pm 2.3$ and $27.7 \pm 1.8 \mathrm{~kg} \mathrm{ha}^{-1} \mathrm{~mm}^{-1}$ for aboveground biomass and grain yield, respectively (Figure 6(a) and (b)). When seasonal water supply was large, the relationship between yield and water supply weakened due to water losses by percolation below root zone and residual soil water at physiological maturity. Simulated percolation averaged $105 \pm 6 \mathrm{~mm}$ for fully irrigated crops and $96 \pm 5$ and $20 \pm 4 \mathrm{~mm}$ for rainfed crops under 'high' and 'low' $\mathrm{ASW}_{\mathrm{S}}$, respectively, and was associated with pre-silking rainfall $\left(p<0.001, r^{2}=0.74,0.78\right.$, and 0.56). Residual ASW at harvest averaged $120 \pm 2 \mathrm{~mm}$ for fully irrigated crops and $88 \pm 3$ and $52 \pm 4 \mathrm{~mm}$ for rainfed crops under 'high' and 'low' $\mathrm{ASW}_{\mathrm{S}}$, respectively, and was associated with post-silking rainfall $\left(p<0.001, r^{2}=0.55,0.63\right.$, and 0.59$)$.

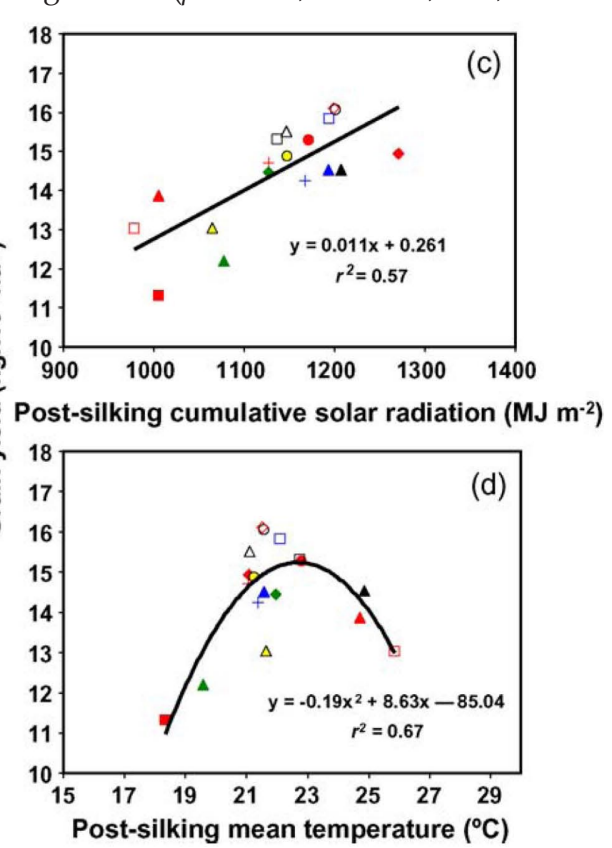

Figure 5. Simulated potential aboveground dry matter yield as a function of total cumulative solar radiation and mean daily pre-silking maximum temperature $(a$ and $b)$, and simulated potential grain yield as a function of cumulative solar radiation and average mean temperature during the post-silking phase (c and d). Each point is the 20-year average at each simulated location (excluding those site-years in which a frost occurred during grain filling) in the Western U.S. Corn-Belt (see Figure 1). All relationships were highly significant $(p<0.001)$. 
Table 3. Pearson's correlations coefficients between the simulated aboveground biomass or grain yield of fully irrigated $(n=295)$ or rainfed $(n=564)$ maize and means of environmental factors computed for the entire crop cycle (ECC), or the pre-silking (Pre-S) or post-silking (Post-S) phases. Site-years in which a frost occurred during grain-filling were not included.

\begin{tabular}{|c|c|c|c|c|}
\hline \multirow[t]{2}{*}{ Environmental factor } & \multicolumn{2}{|c|}{ Fully irrigated crops } & \multicolumn{2}{|c|}{ Rainfed crops ${ }^{\text {a }}$} \\
\hline & Aboveground biomass & Grain yield & Aboveground biomass & Grain yield \\
\hline \multicolumn{5}{|l|}{ Daily radiation } \\
\hline Post-S & $0.56^{* * *}$ & $-0.25^{* * *}$ & $-0.40^{* * *}$ & $-0.43^{* * *}$ \\
\hline ECC & $0.58^{* * *}$ & $-0.15^{* *}$ & $-0.42^{* * *}$ & $-0.42^{* * *}$ \\
\hline \multicolumn{5}{|l|}{ Cumulative radiation } \\
\hline $\mathrm{W}$ & $0.72^{* * *}$ & $0.55^{\star * *}$ & -0.08 & 0.02 \\
\hline \multicolumn{5}{|l|}{ Mean temperature } \\
\hline Pre-S & $0.23^{* * *}$ & -0.02 & $-0.21^{* * *}$ & $-0.22^{* * *}$ \\
\hline Post-S & 0.07 & $-0.40^{* * *}$ & $-0.27^{* * *}$ & $-0.37^{* * *}$ \\
\hline ECC & $0.21^{* * *}$ & $-0.32^{* * *}$ & $-0.27^{* * *}$ & $-0.34^{\star * *}$ \\
\hline \multicolumn{5}{|l|}{ Maximum temperature } \\
\hline Pre-S & -0.01 & 0.11 & $-0.20^{* * *}$ & $0.17^{* *}$ \\
\hline Post-S & $-0.13^{*}$ & $-0.38^{* * *}$ & -0.03 & $-0.14^{*}$ \\
\hline ECC & -0.07 & $-0.16^{* *}$ & 0.08 & -0.01 \\
\hline \multicolumn{5}{|l|}{ Rainfall } \\
\hline Pre-S & $-0.26^{\star *}$ & $0.13^{\star * *}$ & $0.60^{* * *}$ & $0.52^{* * *}$ \\
\hline Post-S & -0.29 & $0.25^{\star * *}$ & $0.59^{* * *}$ & $0.53^{* * *}$ \\
\hline ECC & -0.09 & $0.30^{* * *}$ & $0.71^{* * *}$ & $0.67^{* * *}$ \\
\hline \multicolumn{5}{|l|}{ Relative humidity } \\
\hline Pre-S & $-0.26^{* * *}$ & $0.13^{*}$ & $0.39^{* * *}$ & $0.38^{* * *}$ \\
\hline Post-S & $-0.29^{* * *}$ & $0.25^{\star * *}$ & $0.58^{* * *}$ & $0.57^{* * *}$ \\
\hline ECC & $-0.31^{* * *}$ & $0.21^{* * *}$ & $0.54^{* * *}$ & $0.53^{* * *}$ \\
\hline \multicolumn{5}{|l|}{ Reference ET } \\
\hline
\end{tabular}

${ }^{a}$ Data pooled across initial ASW scenarios.

${ }^{*}$ Correlation at $p<0.05 ;{ }^{* *}$ Correlation at $p<0.01 ;{ }^{* * *}$ Correlation at $p<0.001$

The relationship between aboveground biomass or grain yield and seasonal $\mathrm{ET}_{\mathrm{C}}$ (Figure 6(c) and (d)) had much less scatter compared to plots against seasonal water supply (Figure 6(a) and (b)). Fitted boundary functions for WUE based on $\mathrm{ET}_{\mathrm{C}}$ had slopes $\left(\approx \mathrm{TE}_{\mathrm{S}}\right)$ of $54.4 \pm 5.6$ and $37.0 \pm 1.3 \mathrm{~kg} \mathrm{ha}^{-1} \mathrm{~mm}^{-1}$, respectively, and $x$-intercepts of 25 and $85 \mathrm{~mm}$ ( $\approx$ seasonal soil evaporation) (Figure 6(c) and (d)) which corresponds closely with the range of seasonal soil evaporation simulated by Hybrid-Maize for the Western Corn-Belt (range: $25-79 \mathrm{~mm}$; 7-34\% of the seasonal $\mathrm{ET}_{\mathrm{C}}$ ). Across the 18 locations in our study, the mean simulated $\mathrm{ET}_{\mathrm{C}}$ for fully irrigated crops was $618 \pm 5 \mathrm{~mm}$, which is close to the value of $610 \mathrm{~mm}$ reported for irrigated maize crops grown in the Western Corn-Belt (Loomis and Connor, 1992). Although Hybrid-Maize does not account for other yield-reducing factors such as nutrient deficiencies, weeds, and pests, there was a wide range in yield of up to $6 \mathrm{Mg}$ grain ha ${ }^{-1}$ for both rainfed and fully irrigated crops at a given amount of $\mathrm{ET}_{\mathrm{C}}$ (Figure 6(c) and (d)). Hybrid-Maize simulations identified the primary causes for this variation, which include: (i) post-silking cumulative radiation and temperature under irrigated conditions, (ii) intensity of post-silking water stress under rainfed conditions, and (iii) site differences and within site annual variation in evaporative demand (determined largely by the solar radiation, vapour pressure deficit, and wind speed), and water loss from soil evaporation (data not shown).
Compared to reported values from the literature, the boundary function estimated in our current study appears to be broadly applicable to measured values of WUE from field studies conducted at a number of locations around the world (Figure 7). Nearly all of the measured data points fell well below the attainable productivity delimited by the boundary functions for both aboveground biomass and grain yield. Despite identifying the reasons for differences in WUE across and within environments was not an objective of this paper, we speculate that gaps between the boundary function and the observed data were associated with both environmental limitations such as evaporative demand and water supply distribution, as well as other non-water-related factors such as plant population, nutrient supply, and biotic stresses. Likewise, runoff and percolation below root zone, generally not measured for $\mathrm{ET}_{C}$ calculation, contribute to the observed gap between the boundary function and actual yields, especially in locations with high rainfall.

\section{Discussion}

Maize yields were simulated over a period of 20 years at 18 locations across the Western Corn-Belt using current best-recommended management practices for each location. Geospatial gradients in radiation, temperature, rainfall, and $\mathrm{ET}_{\mathrm{O}}$ gradients had a large impact on maize productivity under both irrigated 

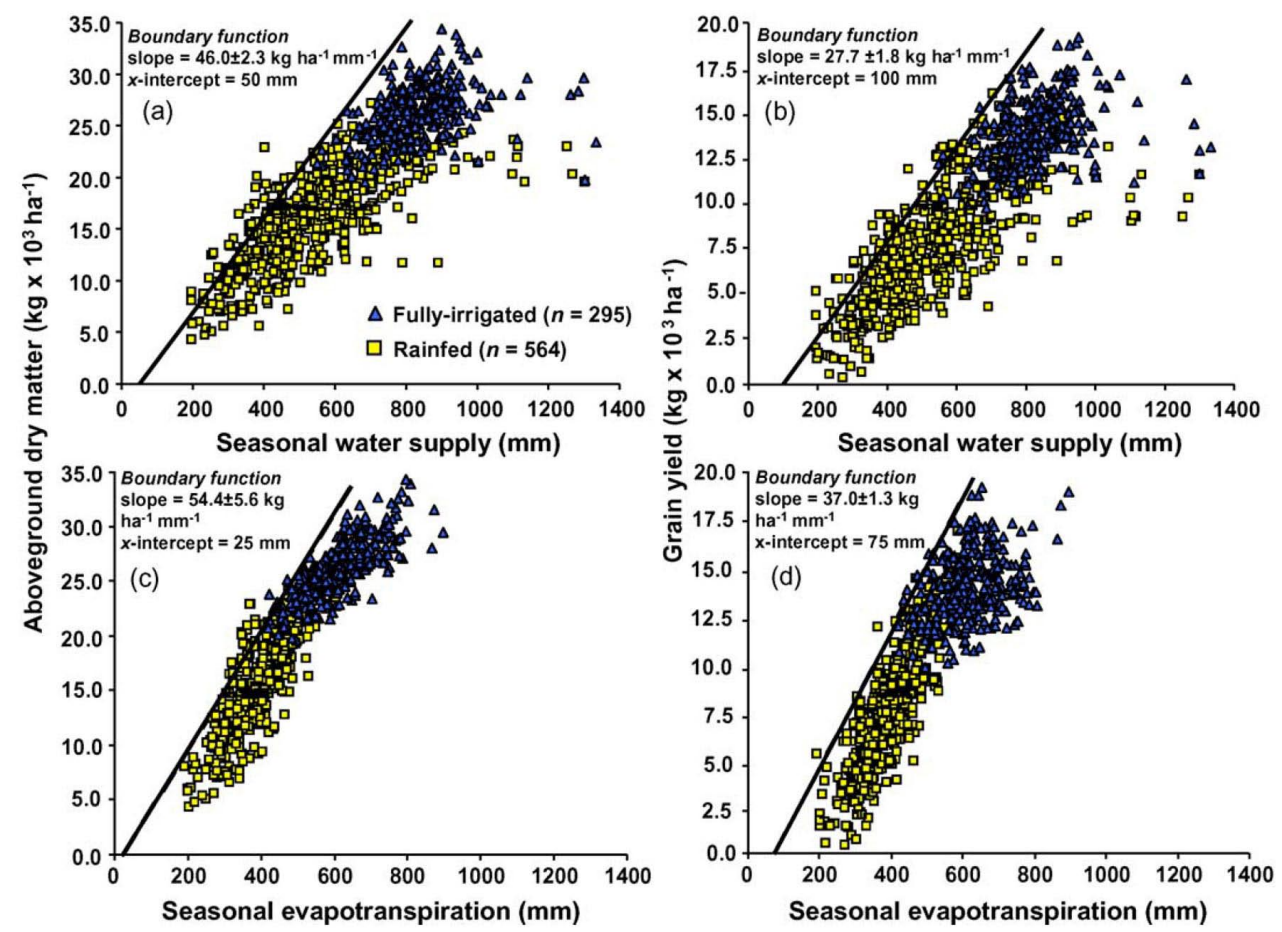

Figure 6. Relationships between simulated aboveground dry matter (left panels) and grain yield (right panels) and seasonal water supply (a and b), and simulated crop evapotranspiration (c and d). Rainfed crops category includes the two initial ASW scenarios. Lines are the boundary functions for water productivity ( $\mathrm{a}$ and $\mathrm{b})$, and water-use efficiency (c and d). Slopes $( \pm$ S.E.) and $x$-intercepts of the boundary functions are shown. Site-years in which a frost occurred during grain filling were not included.

and rainfed conditions. Potential grain yields were closely associated with cumulative incident solar radiation and temperature during the post-silking period while rainfed grain yields were largely governed by the available water supply from initial soil moisture and rainfall.

Maize maximum $\mathrm{TE}_{\mathrm{S}}$ was estimated to be about $37 \mathrm{~kg} \mathrm{ha}^{-1}$ $\mathrm{mm}^{-1}$ for grain yield, and $54 \mathrm{~kg} \mathrm{ha}^{-1} \mathrm{~mm}^{-1}$ for total aboveground biomass. The boundary $\mathrm{TE}_{\mathrm{S}}$ for grain yield estimated here is well above reported values for winter cereals (20$22 \mathrm{~kg}$ grain ha-1 $\mathrm{mm}^{-1}$; Passioura, 2006, Sadras and Angus, 2006), grain legumes (12-20 kg grain ha-1 $\mathrm{mm}^{-1}$; Loss et al., 1997; Zhang et al., 2000), and oilseed crops $\left(8-13 \mathrm{~kg}_{\text {grain }} \mathrm{ha}^{-1} \mathrm{~mm}^{-1}\right.$; Specht et al., 1986; Hocking et al., 1997; Grassini et al., 2009; Dardanelli et al., 1991), which, like our maize estimates, are based on grain yields at standard commercial moisture content for each crop. Except for cases when severe water stress occurs during the sensitive anthesis-silking window (which determines maize kernel number), maize $\mathrm{TE}_{\mathrm{S}}$ for grain yield is expected to be greater than that for other crops because maize carbon fixation occurs via the $C_{4}$ pathway and the energetic cost of its grain is smaller compared to protein-rich legume seed or oilseed crops (Sinclair et al., 1984; Loomis and Connor, 1992).

Analysis of yield determining factors by simulation modeling and regression analysis indicated that meteorological variables estimated separately for pre- and post-sliking periods had greater explanatory power than use of estimates for the entire growing season. Whereas the greatest potential aboveground biomass yield occurs at locations and in years with a long growing-season and a late maturing hybrid, which together maximize cumulative solar radiation, warmer temperatures during the vegetative growth phase also contribute to higher potential biomass yieldspresumably due to increasing photosynthetic rates and/or a more rapid leaf area expansion which leads to an early canopy closure (Andrade et al., 1993; Andrade et al., 1996; Westgate et al., 1997).
Based on recommended planting dates and hybrids, rainfed maize crops experience water stress during the reproductive growth period in a high proportion of years throughout the Western Corn-Belt, although the severity of stress increases along the east-west rainfall gradient. While greater stored soil water content at sowing diminishes the intensity of the water stress during the growing season, it does not eliminate it. Given the high probability of water stress, recommended rainfed plant populations decreased with the east-west rainfall gradient to avoid depletion of soil moisture during the vegetative stage due to a larger leaf area than required to achieve maximum WUE for grain yield. Field studies in Western Nebraska confirm the benefits of reducing maize plant population as the available water supply decreases (Lyon et al., 2003).

The maximum boundary functions for WP and WUE estimated in our study and regional estimates of $\mathrm{ET}_{\mathrm{C}}$ are useful tools for diagnosing productivity constraints to maize yields in water-limited and irrigated environments. Boundary WP and WUE values provide benchmarks that can be used by agronomists and researchers to set realistic productivity goals for a specific irrigated or rainfed environment. Where measured values fall well below these thresholds, the yield gap can be closed by identifying and correcting non-water-related factors that constrain productivity, such as nutrient deficiencies, diseases, and weeds. Large differences between estimates of WP and WUE may indicate greater than average water loss from percolation, surface runoff, or a significant amount of unused water left in the soil profile at maturity. In fact, simulations showed that water losses from percolation and runoff often occur in the same year that a maize crop experiences yield-reducing water stress. Thus, management practices that reduce these losses through healthier root systems, appropriate tillage and residue management, and precise irrigation scheduling and amounts will increase the fraction of available water removed by the crop, 

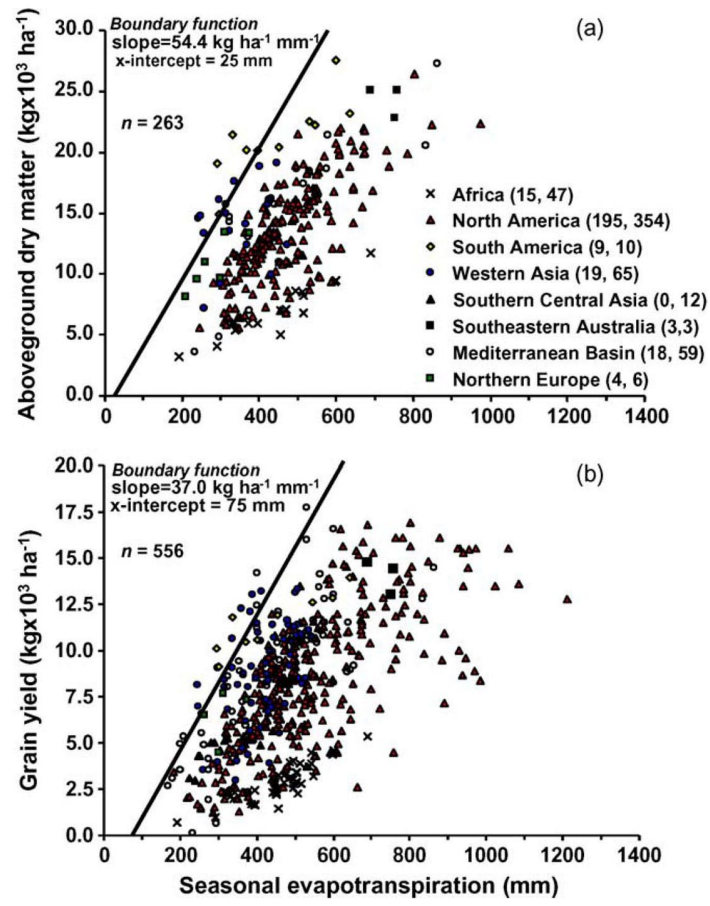

Figure 7. Reported observed maize (a) aboveground dry matter and (b) grain yield/crop evapotranspiration relationships in experiments conducted in low-rainfall environments (Appendix B). For each region, the number of cases for aboveground dry matter and grain yield is indicated, in this order, between brackets. The solid lines are the boundary functions for water-use efficiency shown in Figure 6(c) and (d); their slopes and $x$-intercepts are shown.

decrease the risk or severity of water stress, and improve crop water productivity.

Overall, this study has defined the limits for maize productivity in the Western Corn-Belt. Radiation and temperature determine the ceiling for potential productivity while water supply imposes an upper limit for rainfed crops. Highest potential grain yields are expected at locations where the length of the post-silking phase is maximized, keeping temperatures over the optimum range for kernel growth and carbon net assimilation. Boundary functions derived from this study provide a useful benchmark to analyze water-limited productivity. Finally, simulated and reported data indicate that maize seasonal TE is well above to that reported for winter cereals, grain legumes, and oilseed crops.

\section{Acknowledgments}

We are grateful to Dr. Kenneth Hubbard (University of Nebraska-Lincoln) for providing soil water data from the High Plains Regional Climate Center, Dr. Daniel Walters (University of Nebraska-Lincoln) and Dr. Achim Dobermann (IRRI) for providing data from replicated field experiments with maize for model validation, Dr. María Otegui (University of Buenos Aires, Argentina) for providing additional field experiment data included in Figure 7, Rebecca Davis (Risk Management Agency, USDA) for providing the sowing progression data, and Maribeth Milner (University of Nebraska-Lincoln) for helping with Figure 1, providing access to the soil database, and helping to identify the primary soil type and mean sowing date for each of the 18 locations simulated in this study. The authors also acknowledge the crop management data and information provided by Pioneer Agronomy Sciences, Pioneer Hi-Bred International Inc.

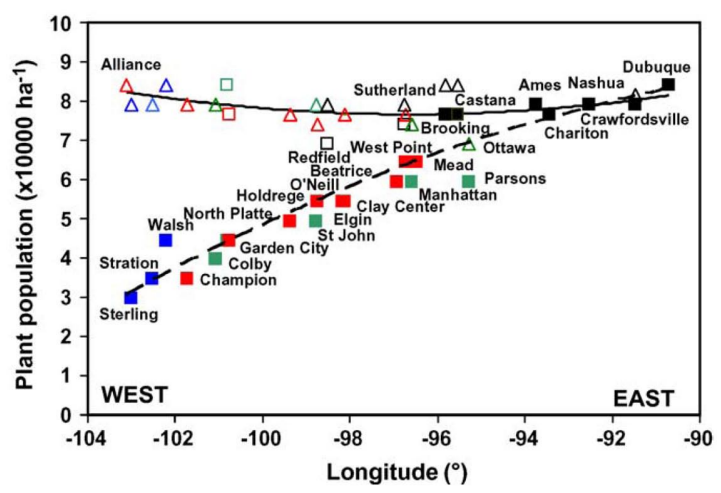

Figure A1. Actual recommended plant populations for irrigated (open triangles, solid line) and rainfed crops (solid squares, dashed line) plotted against longitude in Western U.S. Corn-Belt. Locations are named and colors indicate the state to which each location belongs (Colorado: blue; Iowa: black; Kansas: green; Nebraska: red; South Dakota: black). At some eastern locations, symbols for irrigated and rainfed crops are overlapped. Second-order polynomial functions were fitted for rainfed $\left(y=-0.016 x^{2}-2.65 x-101.5 ; p<0.0001, r^{2}=0.88\right)$ and fully irrigated crops $\left(y=0.013 x^{2}+2.60 x+133.3 ; p>0.10, r^{2}=0.21\right)$. Both functions are shown for comparison, regardless their significance.

The senior author wishes also to acknowledge financial support from the Fulbright Program for his graduate assistantship and the Agricultural Research Division of the Institute of Agriculture and Natural Resources at the University of Nebraska.

\section{Appendix A. Figure A1}

Appendix B. References that were the source of data used in Figure 7, which plots the relationship between aboveground biomass or grain yield versus ET $_{C}$

Allen, R. R., Musick, J. T., 2001. Deep ripping and blocked furrow effects on lower 1/3 furrow irrigation infiltration. Appl. Eng. Agric. 17, 41-48.

Andrade, F. H., Cirilo, A. G., Uhart, S. A., Otegui, M. E., 1996. Ecofisiología del Cultivo de Maíz. La Barrosa and Dekalbpress, Buenos Aires, Argentina.

Ben Nouna, B., Kateriji, N., Mastrorilli, M., 2000. Using the CERES-Maize model in a Mediterranean environment. Evaluation of model performance. Eur. J. Agron. 13, 309-322.

Camp, C. R., Sadler, E. J., 2002. Irrigation, deep tillage, and nitrogen management for a corn-soybean rotation. Trans. ASAE 45, 601-608.

Daðdelen, N., Yýlmaz, E., Sezgin, F., Gürbüz, T., 2006. Water-yield relation and water use efficiency of cotton (Gossypium hirsutum L.) and second crop corn (Zea mays L.) in western Turkey. Agric. Water Manage. 82, 63-85.

Della Maggiora, A. I., Gardiol, J. M., Irigoyen, A. I., 2000. Requerimientos hídricos. In: Andrade, F. H., Sadras, V. O. (Eds.), Bases para el manejo del maíz, el girasol y la soja. INTA-UNMdP, Balcarce, Argentina, pp. 155-171.

Di Paolo, E., Rinaldi, M., 2008. Yield response of corn to irrigation and nitrogen fertilization in a Mediterranean environment. Field Crops Res. 105, 202-210.

Eck, H., 1984. Irrigated corn yields response to nitrogen and water. Agron. J. 746, 421-428.

Farre, I., Faci, J. M., 2006. Comparative response of maize (Zea mays L.) and sorghum (Sorghum bicolor L. Moench) to deficit irrigation in a Mediterranean environment. Agric. Water Manage. 83, 135-143.

Fernandez, J. E., Moreno, F., Murillo, J. M., Cayuekla, J. A., FernandezBoy, E., Cabrera, F., 1995. Water use and yield of maize with two levels of nitrogen fertilization in SW Spain. Agric. Water Manage. 29, 215-233.

Howell, T. A., Copeland, K. S., Schneider, A. D., Dusek, D. A., 1989. Sprinkler irrigation management for corn-southern Great Plains. Trans. ASAE 32, 147-154. 
Howell, T. A., Schneider, A. D., Evett, S. R., 1997. Subsurface and surface microirrigation of corn-southern Great Plains. Trans. ASAE 40, 635-641.

Howell, T. A., Tolk, J. A., Schneider, A. D., Evett, S. R., 1998. Evapotranspiration, yield and water use efficiency of corn hybrids differing in maturity. Agron. J. 90, 3-9.

Howell, T. A., Yazar, A., Schneider, A. D., Dusek, D. A., Copeland, K. S., 1995. Yield and water use efficiency of corn in response to LEPA irrigation. Trans. ASAE 38, 1737-1747.

Igbadun, H. E., Tarimo, A. K. P. R., Salim, B. A., Mahoo H. F., 2007. Evaluation of selected crop water production functions for an irrigated maize crop. Agric. Water Manage. 94, 1-10.

Kang, S., Shi, W., Zhang, J., 2000. An improved water-use efficiency for maize grown under regulated deficit irrigation. Field Crops Res. 67, 207-214.

Kang, S. Z., Shi, P., Pan, Y. H., Liang, Z. S., Hu, X. T., Zhang, J., 2000. Soil water distribution, uniformity and water-use efficiency under alternate furrow irrigation in arid areas. Irrig. Sci. 19, 181-190.

Karam, F., Breidy, J., Stephan C., Rouphael, J., 2003. Evapotranspiration, yield and water use efficiency of drip irrigated corn in the Bekaa Valley of Lebanon. Agric. Water Manage. 63, 125-137.

Kirda, C., Topcu, S., Kaman, H., Ulger, A. C., Yazici, A., Cetin, M., Derici, M. R., 2005. Grain yield response and $\mathrm{N}$-fertiliser recovery of maize under deficit irrigation. Field Crops Res. 93, 132-141.

Lamm, F. R., Manges, H. L., Stone, L. R., Khan, A. H., Rogers, D. H., 1995. Water requirements of sub-surface drip-irrigated corn in northwest Kansas. Trans. ASAE 38, 441-448.

Lamm, F. R., Rogers, D. H., Manges, H. L., 1994. Irrigation scheduling with planned soil water depletion. Trans. ASAE 37, 1491-1497.

Lamm, F. R., Schlegel, A. J., Clark, G. A., 1997. Nitrogen fertirrigation for corn using SDI: A BMP. Pap. No. 972174. ASAE Annu. Meet., Minneapolis, MN, August 10-14, 1997. Am. Soc. Agric. Eng., St. Joseph, MI.

Lamm, F. R., Trooien, H. L., Manges, H. L., Sunderman, H. D., 2001. Nitrogen fertilization for subsurface drip-irrigated corn. Trans. ASAE $44,533-542$.

Li, F., Zhao, S., Geballe, G. T., 2000. Water use patterns and agronomic performance for some cropping systems with and without fallows crop in a semiarid-environment of northwest China. Agric. Ecosyst. Environ. 79, 129-142.

Liu, W. Z., Zhang, X. C., 2006. Optimizing water and fertilizer input using an elasticity index: a case study with maize in the loess plateau of china. Field Crops Res. 100, 302-310.

Lyon, D. J., Boa, F., Arkebauer, T. J., 1995. Water-yield relations of several spring-planted dryland crops following winter wheat. J. Prod. Agric. 8, 281-286.

Mishra, H. S., Rathore, T. R., Savita, U. S., 2001. Water-use efficiency of irrigated winter maize under cool weather condition of India. Irrig. Sci. 21, 27-33.

Musick, J. T., Dusek, D. A., 1980. Irrigated corn yield response to water. Trans. ASAE 23, 92-98.

Norwood, C. A., 2000. Water use and yield of limited-irrigated and dryland corn. Soil Sci. Soc. Am. J. 64, 365-370.

O’Neill, C. J., Humphreys, E., Louis, J., Kutupitiya, A., 2008. Maize productivity in southern New South Wales under furrow and pressurised irrigation. Aust. J. Exp. Res. 48, 285-295.

Ogola, J. B. O., Wheeler, T. R., Harris, P. M., 2002. Effect of nitrogen and irrigation on water use of maize crops. Field Crops Res. 78, 105-117.

Otegui, M. E., Andrade, F. H, Suero, E. E., 1995. Growth, water use, and kernel abortion of maize subjected to drought at silking. Field Crops Res. 40, 87-94.

Panda, R. K., Behera, S. K., Kashyap, P. S., 2004. Effective management of irrigation water under stressed conditions. Agric. Water Manage. 66, 181-203.

Pandey, R. K., Maranville, J. W., Admou, A., 2000. Deficit irrigation and nitrogen effects on maize in a Sahelian environment. I Grain yield and yield components. Agric. Water Manage. 46, 1-13.

Pandey, R. K., Maranville, J. W., Chetimma, M. M., 2000. Deficit irrigation and nitrogen effects on maize in a Sahelian environment. II. Shoot growth, nitrogen uptake and water extraction. Agric. Water Manage. 46, 15-27.

Payero, J. O., Klocke, N. L., Schneekloth, J. P., Davison, D. R., 2006. Comparison of irrigation strategies for surface-irrigated corn in West Central Nebraska. Irrig. Sci. 24, 257-265.
Payero, J. O., Melvin, S. R., Irmak, S., Tarkalson, D., 2006. Yield response of corn to deficit irrigation in semiarid climate. Agric. Water Manage. $84,101-112$.

Persaud, N., Khosla, R., 1999. Partitioning soil-water losses in plant populations of dry-land corn. Agric. Water Manage. 42, 157-172.

Robins, J. S., Domingo, C. E., 1953. Some effects of severe soil moisture deficit at specific growth stages in corn. Agron. J. 45, 618-621.

Sadler, J. E., Bauer, J. P., Busscher, W. J., 2000. Site-specific analysis of a droughted corn crop. I. Growth and grain yield. Agron. J. 92, 395-402.

Sadler, J. E., Bauer, J. P., Busscher, W. J., Millen, J. A., 2000. Site-specific analysis of a droughted corn crop. I. Water use and stress. Agron. J. $92,403-410$.

Sorensen, V. M., Hanks, R. J., Cartee, R. L., 1980. Cultivation during early season and irrigation influences on corn production. Agron. J. $72,266-270$.

Steele, D. D., Stegman, E. C., Gregor, B. L., 1994. Field comparison of irrigation scheduling methods for corn. Trans. ASAE 37, 1197-1203.

Stegman, E. C., 1982. Corn grain yield as influences by timing of evapotranspiration deficits. Irrig. Sci. 3, 75-87.

Stewart, J. I., Danielson, R. E., Hanks, R. J., Jackson, E. B., Hagen, R. M., Pruitt, W. O., Franklin, W. T., Riley, J. P., 1977. Optimizing Crop Production Through Control of Water and Salinity Levels in the Soil. Utah Water Lab. PRWG 151-1. Logan, Utah, pp. 191.

Tolk, J. A., Howell, T. A., Evett, S. R., 1999. Effect of mulch, irrigation, and soil type on water use and yield of maize. Soil Till. Res. 50, 137-147.

Wagger, M. G., Cassel, D. K., 1993. Corn yield and water-use efficiency as affected by tillage and irrigation. Soil Sci. Soc. Am. J. 57, 229-234.

Yazar, A., Howell, T. A., Dusek, D. A., Copeland, K. S., 1999. Evaluation of crop water stress index for LEPA irrigated corn. Irrig. Sci. 18, 171-180.

Yazar, A., Sezen, S. M., Gencel, B., 2002. Drip irrigation of corn in the Southeast Anatolia Project (GAP) area in Turkey. Irrig. Drain. 51, 293-300.

Zhang, X., Pei, D, Hu, C., 2003. Conserving groundwater for irrigation in the North China Plain. Irrig. Sci. 21, 159-166.

Zhang, Y., Kendy, E., Qiang, Y., Changming, L., Yanjun, S., Hongyong, S., 2004. Effect of soil water deficit on evapotranspiration, grain yield, and water-use efficiency in the North China Plain. Agric. Water Manage. $64,107-122$.

\section{References}

Amir and Sinclair, 1991a $>$ J. Amir and T. R. Sinclair, A model of the temperature and solar-radiation effects on spring wheat growth and yield, Field Crops Res. 28 (1991), pp. 47-58.

Amir and Sinclair, 1991b $>$ J. Amir and T. R. Sinclair, A model of water limitation on spring wheat growth and yield, Field Crops Res. 29 (1991), pp. 59-69.

Andrade et al., 1996 F. H. Andrade, A. G. Cirilo, S. A. Uhart and M. E. Otegui, Ecofisiología del Cultivo de Maíz, La Barrosa and Dekalbpress, Buenos Aires, Argentina (1996).

Andrade et al., 1993 F. H. Andrade, S. A. Uhart and A. G. Cirilo, Temperature affects radiation use efficiency in maize, Field Crops Res. 32 (1993), pp. 17-25.

Cade and Noon, 2003 B. S. Cade and B. R. Noon, A gentle introduction to quantile regression for ecologists, Front. Ecol. Environ. 1 (2003), pp. 412-420.

Cassman and Liska, 2007 Cassman, K. G., Liska, A. J., 2007. Food and fuel for all: realistic or foolish? Biofuels Bioprod. Biorefin. 1, 18-23. http://digitalcommons.unl.edu/agronomyfacpub/114/

Cassman et al., 2003 - K. G. Cassman, A. Dobermann, D. T. Walters and H. S. Yang, Meeting cereal demand while protecting natural resources and improving environmental quality, Ann. Rev. Environ. Resour. 28 (2003), pp. 315-358.

Cirilo and Andrade, 1994 A. G. Cirilo and F. H. Andrade, Sowing date and maize productivity. I. Crop growth and dry matter partitioning, Crop Sci. 34 (1994), pp. 1039-1043.

Dardanelli et al., 1991 J. L. Dardanelli, E. E. Suero, F. H. Andrade and J. Andriani, Water deficits during reproductive growth of soybeans. II. Water use and water deficiency indicators, Agronomie 11 (1991), pp. 747-756. 
Dobermann and Walters, 2004 A. Dobermann and D. T. Walters, What was my attainable yield potential for corn in 2003?, Better Crops $\mathbf{8 8}$ (2004), p. 17.

Duncan et al., 1973 W. G. Duncan, D. L. Shaver and W. A. Williams, Insolation and temperature effects on maize growth and yield, Crop Sci. 13 (1973), pp. 187-191.

Duvick and Cassman, 1999 D. N. Duvick and K. G. Cassman, Postgreen revolution trends in yield potential of temperate maize in the North-Central United Sates, Crop Sci. 39 (1999), pp. 1622-1630.

Edmeades and Bolaños, 2001 G. O. Edmeades and J. Bolaños, Issues arising from the use of CERES for tropical maize, Directions in Modeling Wheat and Maize for Developing Countries. Proceedings of the Workshop on CIMMYT El Batan, Mexico, May 4-6, 1998. NRG-GIS Series 01-02, CIMMYT, Mexico, DF (2001), pp. 13-17.

Evans, 1993 L. T. Evans, Crop Evolution, Adaptation and Yield, Cambridge University Press, Cambridge, UK (1993).

French and Schultz, 1984 R. J. French and J. E. Schultz, Water use efficiency of wheat in a Mediterranean-type environment. I. The relation between yield, water use and climate, Aust. J. Agric. Res. 35 (1984), pp. 743-764.

Grassini et al., 2009 P. Grassini, A. J. Hall and J. L. Mercau, Benchmarking sunflower water productivity in semiarid environments, Field Crops Res. 110 (2009), pp. 251-262.

Hall et al., 1982 A. J. Hall, F. Vilella, N. Trapani and C. Chimenti, The effects of water stress and genotype on the dynamics of pollen-shedding in maize, Field Crops Res. 5 (1982), pp. 349-363.

Hocking et al., $1997>$ P. J. Hocking, J. A. Kirkegaard, J. F. Angus, A. H. Gibson and E. A. Koetz, Comparison of canola, Indian mustard and Linola in two contrasting environments. I. Effects of nitrogen fertilizer on dry-matter production, seed yield and seed quality, Field Crops Res. 49 (1997), pp. 107-125.

Hodges et al., $1987 \checkmark$ T. Hodges, D. Botner, C. Sakamoto and J. HaysHang, Using the CERES-Maize model to estimate production of the U. S. cornbelt, Agric. For. Meteor. 40 (1987), pp. 293-303.

Jones and Kiniry, 1986 C. A. Jones and J. R. Kiniry, CERES-Maize: A Simulation Model of Maize Growth and Development, Texas A\&M University Press, College Station, TX (1986).

Kleinbaum et al., $1998 \gg$ D. G. Kleinbaum, L. L. Kupper, K. E. Muller and A. Nizam, Applied Regression Analysis and Other Multivariate Methods (3rd ed.), Duxbury Press, Pacific Grove, CA (1998).

Löffler et al., $2005-$ C. M. Löffler, J. Wei, T. Fast, J. Gogerty, S. Langton, M. Bergman, B. Merrill and M. Cooper, Classification of maize environments using crop simulation and geographic information systems, Crop Sci. 45 (2005), pp. 1708-1716.

Loomis and Connor, 1992 R. S. Loomis and D. J. Connor, Crop Ecology. Productivity and Management in Agricultural Systems, Cambridge University Press, Cambridge (1992).

Loss et al., $1997 \checkmark$ S. P. Loss, K. H. M. Siddique and D. Tennant, Adaptation of faba bean (Vicia Faba L.) to dryland Mediterranean-type environments. III. Water use and water-use efficiency, Field Crops Res. 54 (1997), pp. 153-162.

Lyon et al., 2003 D. J. Lyon, G. L. Hammer, G. B. McLean and J. M. Blumenthal, Simulation supplements field studies to determine notill dryland corn population recommendations for semiarid western Nebraska, Agron. J. 95 (2003), pp. 884-891.

Muchow, 1989 R. C. Muchow, Comparative productivity of maize, sorghum and pearl millet in a semi-arid tropical environment. I. Yield potential, Field Crops Res. 20 (1989), pp. 191-205.

Muchow et al., 1990 R. C. Muchow, T. R. Sinclair and J. M. Bennet, Temperature and solar radiation effects on potential maize yield across locations, Agron. J. 82 (1990), pp. 338-343.

Otegui et al., 1995 M. E. Otegui, M. G. Nicolini, R. A. Ruiz and P. A. Dodds, Sowing date effects on grain yield components for different maize genotypes, Agron. J. 87 (1995), pp. 29-33.

Otegui et al., 1996 M. E. Otegui, R. A. Ruiz and D. Petruzzi, Modeling hybrid and sowing date effects on potential grain yield of maize in a humid temperate region, Field Crops Res. 47 (1996), pp. 167-174.

Otegui and Bonhomme, 1998 M. E. Otegui and R. Bonhomme, Grain yield components in maize. I. Ear growth and kernel set, Field Crops Res. 56 (1998), pp. 247-256.
Passioura, 2006 J. Passioura, Increasing crop productivity when water is scarce-from breeding to field management, Agric. Water Manage. 80 (2006), pp. 176-196.

Payero et al., 2006 J. O. Payero, N. L. Klocke, J. P. Schneekloth and D. R. Davison, Comparison of irrigation strategies for surface-irrigated corn in West Central Nebraska, Irrig. Sci. 24 (2006), pp. 257-265.

Rosegrant et al., 2002 M. W. Rosegrant, X. Cai and S. A. Cline, World Water and Food to 2025: Dealing with Scarcity, International Food Policy Research Institute, Washington, DC (2002) p. 322.

Sadras and Angus, 2006 V. O. Sadras and J. F. Angus, Benchmarking water-use efficiency of rainfed wheat in dry environments, Aust. J. Agric. Res. 57 (2006), pp. 847-856.

Sinclair et al., 1984 T. R. Sinclair, C. B. Tanner and J. M. Bennett, Water-use efficiency in crop production, BioScience 34 (1984), pp. 36-40.

Smika, 1992 - D. E. Smika, Cereal systems of the North American Central Great Plains. In: C. J. Pearson, Editor, Field Crop Ecosystems, Elsevier, Amsterdam (1992), pp. 401-406.

Specht et al., 1986 J. E. Specht, J. H. Williams and C. J. Weidenbenner, Differential response of soybean genotypes subjected to a seasonal soil water gradient, Crop Sci. 26 (1986), pp. 922-934.

Tollenaar and Lee, 2002 M. Tollenaar and E. A. Lee, Yield potential, yield stability and stress tolerance in maize, Field Crops Res. 75 (2002), pp. 161-169.

USDA, 1994 - USDA, 1994. State Soil Geographic (STATSGO) database, user's guide. In: Miscellaneous Publication No. 1492, Nat. Soil Survey Ctr., Soil Conservation Service, Lincoln, Nebraska.

USDA, 1995 - USDA, 1995. Soil Survey Geographic (SSURGO) database. In: Miscellaneous publication No. 1527, Nat. Soil Survey Ctr., Natural Resources Conservation Service, Washington, DC.

USDA-NASS, 2003-2007 USDA-National Agricultural Statistics Service, 2003-2007. Crops U. S. State and County Databases. Washington, DC (online WWW). Available URL: http://www.nass.usda. gov/index.asp (accessed October 1, 2008).

USDA-NRCS, 2007 USDA-Natural Resource Conservation Service. Official Soil Series Descriptions. Lincoln, NE (online WWW). Available URL: http://soils.usda.gov/technical/classification/osd/index. html (accessed October 20, 2007).

van Ittersum and Rabbinge, $1997-$ M. K. van Ittersum and R. Rabbinge, Concepts in production ecology for analysis and quantification of agricultural input-output combinations, Field Crops Res. 52 (1997), pp. 197-208.

Wallace, $2000 \rightarrow$ J. S. Wallace, Increasing agricultural water use efficiency to meet future food production, Agric. Ecosyst. Environ. 82 (2000), pp. 105-119.

Westgate and Boyer, 1986 M. Westgate and J. Boyer, Reproduction at low silk and pollen water potentials in maize, Crop Sci. 26 (1986), pp. 951-956.

Westgate et al., 1997 M. E. Westgate, F. Forcella, D. C. Reicosky and J. Somsen, Rapid canopy closure for maize production in the Northern US Corn-Belt: radiation-use efficiency and grain yield, Field Crops Res. 49 (1997), pp. 249-258.

Wilson et al., $1995-$ D. R. Wilson, R. C. Muchow and C. J. Murgatroyd, Model analysis of temperature and solar radiation limitations to maize potential productivity in a cool climate, Field Crops Res. 43 (1995), pp. 1-18.

Yang et al., $2004-$ H. S. Yang, A. Dobermann, J. L. Lindquist, D. T. Walters, T. J. Arkebauer and K. G. Cassman, Hybrid-Maize: a maize simulation model that combines two crop modeling approaches, Field Crops Res. 87 (2004), pp. 131-154; http://digitalcommons.unl. edu/agronomyfacpub/137/

Yang et al., 2006 Yang, H. S., Dobermann, A., Cassman, K. G., Walters, D. T., 2006. Hybrid-Maize (ver. 2006). A Simulation Model for Corn Growth and Yield. Nebraska Cooperative Extension CD 9, University of Nebraska-Lincoln, Lincoln, NE. Available URL: http:// www.hybridmaize.unl.edu/UserGuide.htm

Zhang et al., $2000 \triangleright$ H. Zhang, M. Pala, T. Oweis and H. Harris, Water use and water-use efficiency of chickpea and lentil in a Mediterranean environment, Aust. J. Agric. Res. 51 (2000), pp. 295-304. 